\title{
CLINICO- PATHOLOGICAL PROFILE OF PATIENTS WITH BREAST DISEASES AT UNIVERSITY HOSPITAL, JAMSHORO
}

\author{
K. Altaf H. Talpur, Abdul Aziz Laghari, Arshad Mehmood Malik and Aisha Memon
}

\begin{abstract}
OBJECTIVES: To assess various disorders of breast regarding their frequency, presentation, pathology and management at a University Hospital.

DESIGN: A descriptive study.

SETTING: Department of Surgery, Liaquat University Hospital Jamshoro - Sindh from January 1999 to December 2003.

PATIENTS AND METHODS: One hundred and fifty patients with different breast disorders were studied. All cases were assessed clinically by getting history on a predesigned proforma and diagnosis was confirmed with help of relevant investigations. Patients with various breast diseases were included in the study except those who were having either no definite lump or no breast pathology. The treatment given was according to type of lesion in the form of surgery or conservative. Patients with benign breast diseases were assured and followed up after surgical treatment or kept on hormone therapy where as cases with malignant disease were referred to oncologist for cancer registry purpose and chemo-radiotherapy.

RESULTS: Among 150 cases, majority was females with female to male ratio of 24:1. All patients presented with breast lump (100\%), followed by pain in the lump (53.33\%) as main symptoms. Left breast was involved in $53.33 \%$ and right breast in $44.66 \%$ of cases. Majority of cases (84.67\%) underwent surgery. Histopathology revealed fibro-adenoma in $30.66 \%$, fibrocystic disease in $\mathbf{1 5 . 3 3} \%$ and carcinoma in $\mathbf{3 5 . 3 3} \%$ cases as main disorders. All six male patients had gynaecomastia.

CONCLUSION: In our set up, frequency of carcinoma of breast is increasing as compared to benign lesions. However, overall benign problems are more frequent than breast cancer.
\end{abstract}

KEY WORDS: Breast diseases. Pathology. Malignancy. Surgery.

\section{INTRODUCTION}

Breast conditions cover a spectrum of breast problems comprising of breast diseases and disorders. Differentiation of breast disorders from breast diseases is probably best done in terms of incidence and clinical effect. Conditions that are common and have little clinical significance are considered disorders rather than diseases. ${ }^{1}$ Breast diseases are mostly confined to females because of more complex structure, greater volume and influence of endocrine hormones where as male breasts are rudimentary nonfunctional organ, relatively insensitive to endocrine stimuli and apparently resistant to neoplastic growth. ${ }^{2}$ Breast tissue in females is under the influence of various hormones and subjected to constant physiological changes throughout reproductive life and beyond. These changes lead to a number of pathological conditions; both benign and malignant. ${ }^{3}$ Common breast lesions in females include fibro-adenoma, fibrocystic disease followed by ductal carcinoma where as gy- naecomastia is only found in male breast. ${ }^{4}$ Benign breast disorders constitute the major work load in breast clinics ${ }^{5}$ and about $12 \%$ of palpable lumps are neoplastic, therefore probability of cancer must be excluded while examining a woman with swelling in the breast. $^{3}$ Breast cancer is the commonest malignancy of women in western world and second most common in developing countries. ${ }^{6}$ It arises at a rate of approximately $2 \%$ per year worldwide and this balance is offset mainly by developing countries. ${ }^{7}$ Carcinoma of breast is also most important disease in Pakistan accounting for $25 \%$ of all cancers in females. ${ }^{8}$ Yet majority of patients suffer from benign breast diseases and cancer accounts for only $10 \%$ of cases as assessed by Pattinato $G$, et al in their study. ${ }^{9}$ Most breast diseases present as a palpable lump, mastalgia and nipple discharge. ${ }^{10}$ Although most lumps are benign but the neoplasm constitutes the most important lesions of the female breast. Due to increased public awareness about cancer, the appearance of a lump causes great concern to the patient. Evaluation and 
diagnosis of breast diseases involves the triple assessment that is clinical history and examination, radiological imaging and tissue sample taken for either cytological or histological analysis. ${ }^{11}$ Ultrasonography and mammography, fine needle aspiration cytology (FNAC) and core biopsy are the investigations of choice for diagnosis of majority of breast conditions.

The aim of this study was to evaluate the patients of various breast diseases regarding their presentation, frequency and pathology in our tertiary care set up.

\section{PATIENTS AND METHODS}

This descriptive study of 150 cases admitted in the Department of Surgery, Liaquat University Hospital, Jamshoro was conducted from January 1999 to December 2003. It included patients with different breast disorders comprising of benign and malignant lesions in various age groups. Sampling strategy was convenient and patients with symptoms of breast disorders having no obvious lump or proved to be having no breast disease were excluded from the study. The history of each patient was taken at the time of admission on a predesigned proforma. The lesions were first assessed by clinical examination and then supported by relevant investigations like ultrasonography of breast, X-ray mammography, FNAC and Tru-cut biopsy whereever indicated appropriately along with other base line investigations. Ultrasound examination was carried out in those patients where the lumps were of ill-defind nature or for purpose of differentiation between solid and cystic lesions. Mammography was indicated in patients having bulky breast with clinically doubtful lumps or in cases with suspicious malignancy. Treatment was planned according to the type of disease in the form of conservative or surgery. Patients with fibrocystic disease were assured and treated by medical therapy where as all other cases having surgically manageable disease were submitted for surgery in the form of incision and drainage, excisional biopsy, lumpectomy, simple mastectomy with axillary sampling or clearance. Data analysis was done by SPSS 10.0 version.

\section{RESULTS}

Out of total 150 patients, 144 were female and 6 male with female to male ratio of $24: 1$. Their age ranged from 10 to 80 years and majority (52.66\%) belonged to $2^{\text {nd }}$ or $3^{\text {rd }}$ decade of life (Table I). Frequency of diseases decreased with age and only one case was seen in $8^{\text {th }}$ decade. All patients presented with breast lump (100\%) followed by pain in the lump (53.33\%) as shown in Table II. Left breast was affected in 53.33\% of cases, right in $44.66 \%$ cases where as both breasts were involved in only $2 \%$ of cases. All patients were investigated with baseline investigations but diagnosis was made by special investigations like ultrasound of breast, mammography and cytology/biopsy. Mammography was done in $70(46.66 \%)$ cases, ultrasonography and FNAC/cytology in $90(60 \%)$ cases each while true-cut biopsy in 20 (13.33\%) cases respectively. Majority of patients (84.67\%) was treated surgically whereas $23(15.33 \%)$ received medical treatment. Lumpectomy (30.67\%), excisional biopsy (10 .0\%) and simple mastectomy with axillary sampling or clearance $(25.33 \%)$ were main surgical procedures performed (Table III). Histopathology revealed fibroadenoma in $30.66 \%$, fibrocystic disease in $15.33 \%$ and carcinoma in $35.33 \%$ of cases. All 6 male patients were diagnosed with gynaecomastia (Table IV).

TABLE I:

AGE-WISE DISTRIBUTION OF CASES $(n=150)$

\begin{tabular}{|c|c|c|}
\hline Age (in years) & $\begin{array}{c}\text { Number of } \\
\text { patients }\end{array}$ & Percentage \\
\hline $10-20$ & 42 & 28.00 \\
\hline $21-30$ & 37 & 24.66 \\
\hline $31-40$ & 27 & 18.00 \\
\hline $41-50$ & 21 & 14.00 \\
\hline $51-60$ & 17 & 11.33 \\
\hline $61-70$ & 05 & 3.33 \\
\hline $71-80$ & 01 & 0.66 \\
\hline Total & 150 & 99.98 \\
\hline
\end{tabular}

TABLE II:

CLINICAL PRESENTATION OF CASES

\begin{tabular}{|l|c|c|}
\hline \multicolumn{1}{|c|}{ Presentation } & $\begin{array}{c}\text { Number of } \\
\text { patients }\end{array}$ & Percentage \\
\hline Breast lump & 150 & 100 \\
\hline Pain in lump & 80 & 53.33 \\
\hline Lump in axilla & 15 & 10.00 \\
\hline Nipple discharge & 05 & 3.33 \\
\hline
\end{tabular}


K. Altaf H. Talpur, Abdul Aziz Laghari, Arshad Mehmood Malik, et al.

TABLE III: MANAGEMENT PATTERN OF CASES

\begin{tabular}{|l|l|c|c|}
\hline \multicolumn{2}{|c|}{ Procedure } & $\begin{array}{c}\text { Number of } \\
\text { patients }\end{array}$ & Percentage \\
\hline 1. & Non surgical & 23 & 15.33 \\
\hline 2. & Surgical & 127 & 84.67 \\
\hline i- Incision and drainage & 07 & 4.67 \\
\hline ii-Lumpectomy & 46 & 30.67 \\
\hline iii- Excisional biopsy & 15 & 10 \\
\hline iv- Simple mastectomy & 35 & 23.33 \\
\hline $\begin{array}{l}\text { v- Simple mastectomy } \\
\text { vi- Subcutaneous } \\
\text { mastectomy }\end{array}$ & 18 & 12 \\
\hline
\end{tabular}

TABLE IV:

HISTOPATHOLOGICAL FINDINGS

\begin{tabular}{|l|c|c|}
\hline \multicolumn{1}{|c|}{ Histopathology } & $\begin{array}{c}\text { Number of } \\
\text { patients }\end{array}$ & Percentage \\
\hline Fibro-adenoma (3 Bil.) & 46 & 30.66 \\
\hline Fibro-cystic disease & 23 & 15.33 \\
\hline $\begin{array}{l}\text { Fibro-adenoma + Fibro- } \\
\text { cystic disease }\end{array}$ & 02 & 1.33 \\
\hline Carcinoma breast & 53 & 35.33 \\
\hline Breast abscess & 07 & 4.67 \\
\hline Chronic mastitis & 10 & 6.67 \\
\hline Tuberculosis & 03 & 2.00 \\
\hline Gynaecomastia & 06 & 4.00 \\
\hline Total & $\mathbf{1 5 0}$ & $\mathbf{9 9 . 9 9}$ \\
\hline
\end{tabular}

\section{DISCUSSION}

There are a number of clinical conditions both benign and malignant which affect the breast at different age periods. In this study, majority of patients presented in $2^{\text {nd }}(28 \%), 3^{\text {rd }}(24.66), 4^{\text {th }}(18 \%)$ and $5^{\text {th }}(14 \%)$ decades with maximum number of cases in $2^{\text {nd }}$ and $3^{\text {rd }}$ (52.66\%) decades of life whereas almost same incidence of diseases was seen in $2^{\text {nd }},(17.03 \%), 3^{\text {rd }}$ (29.63), $4^{\text {th }}(26.53 \%)$ and $5^{\text {th }}$ decades $(16.23 \%)$ as reported by Siddiqui $\mathrm{K}$, et al with highest number in $3^{\text {rd }}$ decade. ${ }^{3}$ Overall, breast problems are commonly seen in females as compared to males. ${ }^{2}$ Similarly, in this study also females were more affected than males with female to male ratio of $24: 1$. Clinically, most of the patients present with history of breast lump, pain in the breast or lump and nipple discharge or retraction. ${ }^{1}$ In this study, all cases presented with features of breast lump, $53.33 \%$ cases with pain in lump, $10 \%$ with lump in axilla and $3.33 \%$ patients with nipple discharge. However, Kumar, et al has reported breast pain as first symptom and lump in the breast as second most common presentation of all breast disorders. ${ }^{12}$ Mammography, ultrasound and FNAC are diagnostic investigations for any breast lesion and same was carried out in this study population. Breast ultrasound is the modality of choice for evaluation and management of patients with breast symptoms or mammographic abnormalities. ${ }^{13}$ Most benign and malignant lesions can be accurately categorized as a result of improvements in grey scale imaging and the development of colour doppler vascular mapping. ${ }^{14}$ Wide range of mammary lesions can also be diagnosed on FNAC with sensitivity of $96.36 \%$ and specificity of $97.56 \% .{ }^{15}$ In this study, $60 \%$ of cases were diagnosed through FNAC.

Fibro-adenoma is the commonest benign breast disease in young females ${ }^{16-19}$, however it is not as common as reported in European series. Fibrocystic disease which is a histologic term and refers clinically to a large group of conditions, make next common benign problem. ${ }^{15}$ As advocated by Siddique MS, et al in their study, carcinoma of breast is most commonly encountered lesion followed by the benign lesions such as fibro-adenoma, fibrocystic disease and other problems. ${ }^{20}$ In this study, benign disorders comprised of $64.33 \%$ and breast cancer among $35.33 \%$ cases. In benign disorders, fibro-adenoma was diagnosed in $30.66 \%$ cases and fibrocystic disease in $15.33 \%$ cases. Other conditions included chronic mastitis in $6.67 \%$ and breast abscess in $4.67 \%$ of female patients and gynaecomastia in $4 \%$ of male patients. Incidence of malignant diseases by different researchers reported is $24.2 \%$ by Choudhary $I A$, et $\mathrm{al}^{21}, 19.67 \%$ by Qureshi $\mathrm{JN}$, et $\mathrm{al}^{22}$ and $31.5 \%$ by Mansoor I. ${ }^{23}$ These figures are comparable with our study.

Chronic mastitis (6.67\%) and breast abscess (4.67\%) were common inflammatory lesions in this study. However, the incidence of non-puerperal abscesses associated with mastitis has been increasing as reported 
by Benso EA. ${ }^{24}$ Tuberculosis is a rare disease affecting the breast in $1.06 \%$ of cases as observed by Alagaratnam TT, et al in their study ${ }^{25}$ and slightly different results has been noted in this study (2.0\%). However, the incidence of tuberculosis seen by Hanif $A$, et $\mathrm{al}^{26}$ is quite high (23\%) as compared to this study.

Gynaecomastia accounted for $4 \%$ of cases in this study being the commonest lesion of male breast. However, Abdullah, et al have reported $11.2 \%$ incidence of gynaecomastia in their population. ${ }^{5}$

In conclusion, carcinoma of breast has increased frequency in our set up when compared with others. Benign breast diseases are also more frequent and among benign lesions fibro-adenoma is the most common lesion followed by fibrocystic disease.

\section{REFERENCES}

1. Edwards P, Gateley C. The Breast. Benign breast disorders and mastalgia. Surg Int. 2001; 53:105-8.

2. Robbins SL. Cotran RS, Kumar V. The Breast. In Robbins, Cotran, Kumar pathologic basis of diseases. $5^{\text {th }}$ edition. W.B. Saunders Philadelphia. 1994: Pp.1089-1111.

3. Siddiqui K, Rasool MI. Pattern of breast diseases: preliminary report of a breast clinic. J Coll Physicians Surg Pak. 2001; 11(8):497-500.

4. Jamal AA. Pattern of breast diseases in the teaching hospital Jaddah, Saudi Arabia. Saudi Med J. 2001; 22(2):110-3.

5. Hameed H, Fentiman IS. Benign breast disease. Int J Clin Pract. 2001; 55(7): 461- 4.

6. Harris J, Morrow M, Norton L. Malignant tumours of breast: In: Devita VT Jr, Hellman S, Rosenberg SA (eds). Cancer principles and practice of oncology. $5^{\text {th }}$ edition. Lippincot Philadelphia.1997: Pp. 1557-1616.

7. Parkin DM, Pisani P, Farlay J. Estimates of worldwide mortality from eighteen major cancers in 1985. Int J Cancer. 1993; 54: 955-601.

8. Pakistan Medical Research Council Cancer Study Group. Frequency of malignant tumours in seven centres of Pakistan. J Pak Med Assoc. 1977; 27:335-9.

9. Pattinato G, Panico L, de Rosa NI, Antonio A, Bifano $D$, Avallone M. Benign lesions of breast. Ann Ital Chir. 1997; 62(2):151-66.
10. Abdullah P, Mubark A, Zahir N, Rehman Z, Sattar A. Mahmood A. Breast lumps - What they actually present? J Coll Physicians Surg Pak. 1999; 9(1): 46-48.

11. Siansbury RC. The Breast. Investigation of breast symptoms. In Russel RCG, Williams NS and Bulstrode CJK. Baily and Love's short practice of surgery. $24^{\text {th }}$ edition. Arnold, London. 2004; Pp. 82446.

12. Kumar A, Vohra LS, Bhargava S, Reddy PS. Investigation of breast lumps: an evaluation. MJAFI. 1999: 55(4):299-302.

13. Kossoff MB. Ultrasound of the breast. Word J Surg. 2000; 24(2): 143-57.

14. Sevensson WE. The value of ultrasound scanning in breast disease. Hosp Med. 2000; 61 (4): 233-9.

15. Hussain N, Bukhari $\mathrm{MH}$ and Naveed IA. An experience of fine needle aspiration cytology in diagnosis of breast lesions at $\mathrm{CMH}$ Gujranwala. Biomedica. 2001;17:37-40.

16. Adeniji KA, Adelusda KA, Odesanmi WO. Benign diseases of the breast in 1Le - Lfe: a 10 years experience and literature review. Cent Afr J Med. 1997; 43:140 - 3.

17. Viviani RS, Gebrim LH, Baracat EC, de Lima GR. Evaluation of the ultrasonic volume of breast fibroadenomas in women treated with Tamoxifen. Minerva Ginecol. 2002; 54(4): 531-5.

18. Amshel CE, Sibley E. Multiple unilateral fibroadenomas. Breast J. 2001; 189-91.

19. Houssami N, Cheung MN, Dixon JM. Fibroadenama of the breast. Med J Aust. 2001; 1744 (4): 185-8.

20. Siddique MS, Kayani N, Gill MS, Pervaiz S, Muzaffar S, Aziz SA, et al. Breast diseases: a histopathological analysis of 3279 cases at a tertiary care centre in Pakistan. J Pak Med Assoc. 2003;53 (3): 94-7.

21. Chaudhary IA, Qureshi SK and Rasul S. Incidence of malignancy in females presenting with breast lumps in OPD: a study of 277 cases. Pak J Med Sci. 2003;19 (4): 287-94.

22. Qureshi JN, Qureshi ZA, Ahuja P, Memon AS. Evaluation of carcinoma in breast lump. J Surg Pak. 2001; 6 (3): 7-9. 
23. Mansoor I. Profile of female breast lesions in Saudi Arabia . J Pak Med Assoc. 2001; 51(7)43-7.

24. Benso EA. Management of breast abscesses. World J Surg. 1989; 13: 753-6.
25. Alagaratnam TT, Ong GB. Tuberculosis of the breast. Br J Surg. 1980; 67: 125-6.

26. Hanif A, Mushtaque M, Malik K, Khan A. Tuberculosis of breast. J Surg Pak. 2002; 7 (3): 26-8.

AUTHOR AFFILIATION:

Dr. K. Altaf H. Talpur (Corresponding Author)

Assistant Professor, Department of Surgery

Liaquat University of Medical and Health Sciences

(LUMHS), Jamshoro - Sindh.

Dr. Abdul Aziz Laghari

Associate Professor, Department of Surgery

LUMHS, Jamshoro - Sindh.

Dr. Arshad Mehmood Malik

Assistant Professor, Department of Surgery

LUMHS, Jamshoro - Sindh.

Dr. Aisha Memon

Assistant Professor, Department of Surgery

LUMHS, Jamshoro - Sindh. 